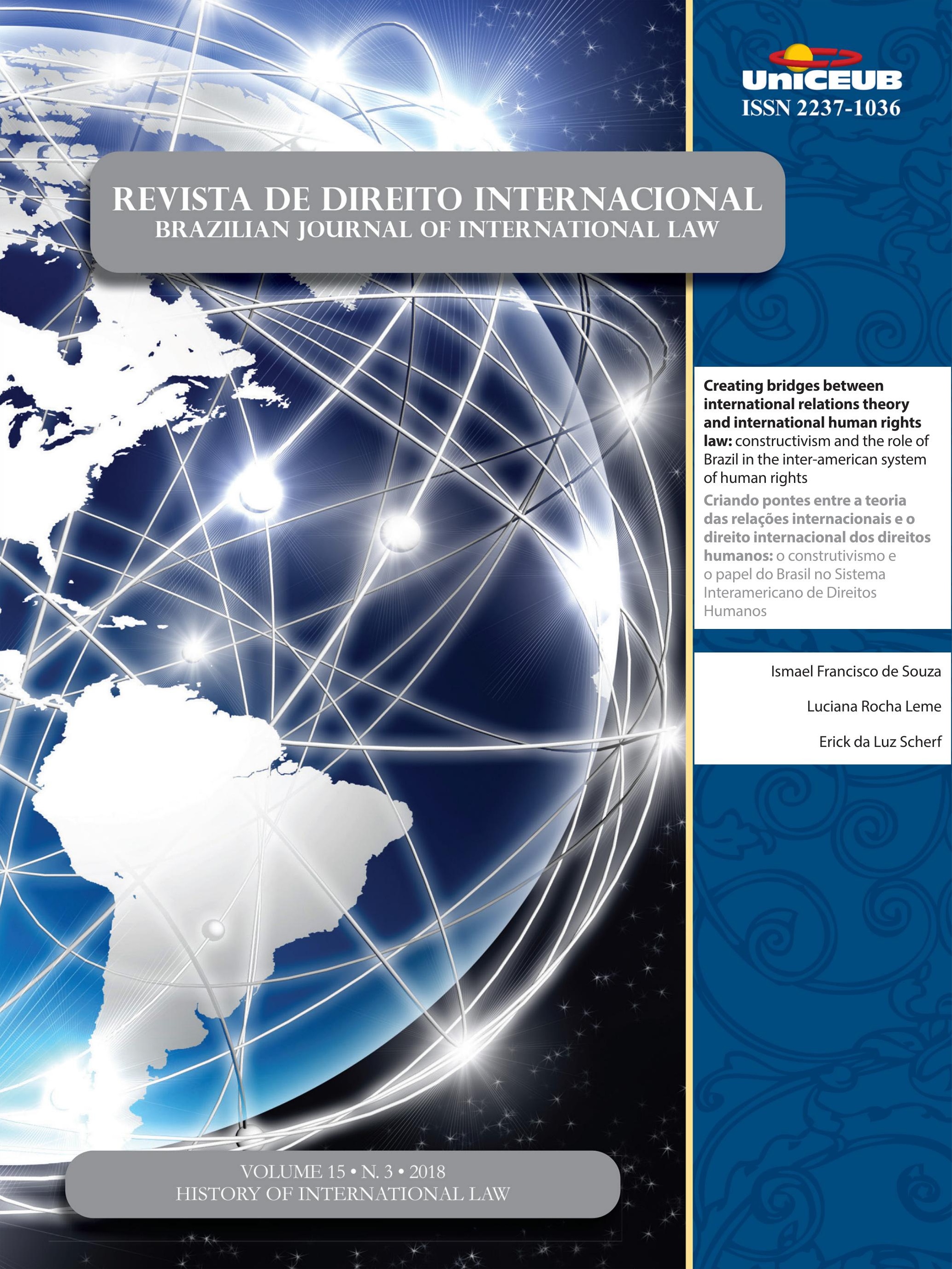




\section{Sumário}

I. Dossiê Especial: History of International Law ...................................1

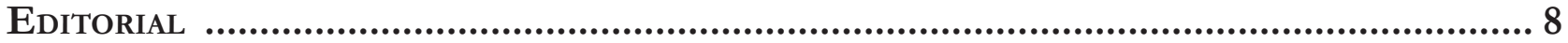

What does it mean to apply history in international law studies? ....................................................... 8

Arthur Roberto Capella Giannattasio

SuR LA NATURE DU Droit ISLAMIQUe............................................................................14

Hocine Benkheira

Islamic Shari’a Law, History and Modernity: Some Reflections .................................25 Suleiman A. Mourad

The (Un)practical Secularization Process: International Law and Religion as So-

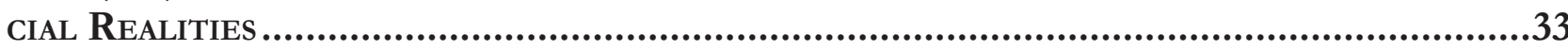

Douglas de Castro

BRAZILIAN LITERATURE ON INTERNATIONAL LAW DURING THE EMPIRE REGIME. OR THE DIFFUSION OF INTERNATIONAL LAW IN THE PERIPHERIES THROUGH APPROPRIATION AND ADAPTATION.

Airton Ribeiro da Silva Júnior

Natural, POSitivo, romano E Universal? INVESTigaÇão SObre O Direito das GENTES EM

Tomás de Aquino

Rafael Zelesco Barretto

II. Artigos sobre outros temas

VINCULAÇÃO DOS DIREITOS ECONÔMICOS, SOCIAIS E CULTURAIS: UMA DISCUSSÃO DO DESENVOLVImento humano com base no conceito de Amartya Sen sobre o mínimo existencial.....99

Natalia Mascarenhas Simões Bentes e Yasmim Salgado Santa Brígida

A NOVA LeI de MigraÇão E A PROTEÇão CONFERIDA AO APÁtrida: ALINHAMENTO BRASILEIRO AO PADRÃO INTERNACIONAL DE DIREITOS HUMANOS

Pedro Henrique de Faria Barbosa e Sylvio Loreto

E se o Supremo Tribunal Federal (STF) restabelecer a vigência da Convenção n. 158 
da Organização Internacional do Trabalho (OIT) na ordem Jurídica brasileira? SoBRE UMA POSSÍVEL REVIRAVOLTA, PELA VIA DO DIREITO INTERNACIONAL, DAS LEIS TRABALHISTAS BRASILEIRAS 138

Daniel Damasio Borges

JULGADOS DA CORTE INTERAMERICANA SOBRE CASOS BRASILEIROS E POLÍTICAS PÚBLICAS: REFLEXÕES ACERCA DE POSSÍVEIS INFLUIÇÕES 165

Rafael Osvaldo Machado Moura

CREATING BRIDGES BETWEEN INTERNATIONAL RELATIONS THEORY AND INTERNATIONAL HUMAN RIGHTS LAW: CONSTRUCTIVISM AND THE ROLE OF BRAZIL IN THE INTER-AMERICAN SYSTEM OF HUMAN RIGHTS 179

Ismael Francisco de Souza, Luciana Rocha Leme e Erick da Luz Scherf

Justiça de transição na Argentina e o Sistema Interamericano de Direitos Humanos: uMa ANÁlise do CASo Luis Muiña (“REgRa 2x1”) 199

Emilio Peluso Neder Meyer e Jessica Holl

A legalidade e legitimidade da INTERVEnÇão humanitÁria: UMA MEDIDA AINDA NECESSÁRIa.219 Natália Caye Batalha Boeira

O Acordo de Escazú E o ACESSo À INFORMaÇão AMbiental no Brasil. 252 Érica Bezerra Queiroz Ribeiro e Bruno Amaral Machado

Dos POVOS NATIVOS AO SURGIMENTO DOS MOVIMENTOS SOCIAIS: INFLUÊNCIAS DOS DISCURSOS JURÍDICOS, RELIGIOSOS E MÉDICOS PARA A CONSTRUÇÃO DO CONCEITO DE HOMOSSEXUALIDADE NO BRASIL .267 Bruno Rafael Silva Nogueira Barbosa e Robson Antão de Medeiros

Aspectos Jurídicos da PARTicipaÇão dA UNião Europeia NA OMC: COMPREENDENdo SUTILEZAS DE UM DELICADO ENLACE. 291

Camilla Capucio

Path to judicial activism? The use of "Relevant rules of international law" by the WTO Appellate Body

Mariana Clara de Andrade

LEVEZA E PESO NA MEDIAÇÃO COMERCIAL INTERNACIONAL: O CONTEÚDO JURÍDICO DO ACORDO CORPORATIVO MEDIADO E SUA INCORPORAÇÃo PELO DiREITO BRASILEIRO .324 Henrique Lenon Farias Guedes 
JURISDIÇÃO INTERNACIONAL E AS DIFICULDADES DE EXECUÇÃO DE SENTENÇAS INTERNACIONAIS NO BRASIL

Nevitton Vieira Souza

O DEVER DE COOPERAÇÃo NOS CONTRATOS DE VENDA INTERNACIONAL DE MERCADORIAS: PRESSUPOSTOS TEÓRICOS E REPERCUSSÕES PRÁTICAS DA CLÁUSULA GERAL DA BOA-FÉ OBJETIVA PARA A APLICAÇÃo DA CISG .358

Angelo Gamba Prata de Carvalho

A DiMENSÃo JURÍdiCA DO IMPERIALISMO NA (DES)ORDEM GLOBAL CAPITALISTA: UMA ANÁLISE COM BASE NA CRÍTICA MARXISTA AO DIREITO INTERNACIONAL E ÀS RELAÇÕES POLÍTICO-ECONÔMICAS DE DOMINAÇÃO E DEPENDÊNCIA.

Thomaz Delgado De David, Maria Beatriz Oliveira da Silva e Rosane Beatris Mariano da Rocha Barcellos Terra

A participaÇão de Brasil e Estados Unidos na formulação das regras multilaterais do

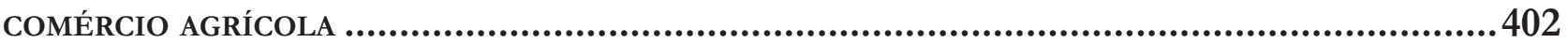

Vera Thorstensen, Vivian Daniele Rocha Gabriel e Alebe Linhares Mesquita

A galáxia lex e a construÇão de um Sistema jurídico transnacional ........................ 441

Eugênia Cristina Nilsen Ribeiro Barza e Jéssyka Maria Nunes Galvão

Has the Ability of Truth Commissions to Recommend Amnesty Been Effective in Enhancing Perpetrator Cooperation? 453 Jeremy Sarkin

A CONCEPTUAL PAPER ON THE POLICY-FRAMEWORK THAT MIRRORS THE DYNAMIC LINK BETWEEN Human Security, Social Protection and Safety Nets, and Food and Nutritional Security: The Case of the "Gulayan sa Paaralan Program", the Philippines.... 478 Renato Lagapa Base

INCENTIVISING SMALLHOLDER FARMER LIVELIHOODS AND CONSTRUCTING FOOD SECURITY THROUGH HOME-GROWN SCHOOL FEEDING: EVIDENCE FROM NORTHERN GHANA .491

Clement Mensah

Policy COHERENCE In THE IMPLEMENTATION OF THE 2030 AgENDA FOR SUSTAINABLE DEVELOpment: the Brazilian School Feeding Programme Case Study .506 Mariana Werlang Girardi 


\title{
Creating bridges between international relations theory and international human rights law: constructivism and the role of Brazil in the inter-american system of human rights*
}

\author{
Criando pontes entre a teoria das relações \\ internacionais e o direito internacional dos \\ direitos humanos: o construtivismo e o papel \\ do Brasil no Sistema Interamericano de Direitos \\ Humanos
}

\author{
Ismael Francisco de Souza** \\ Luciana Rocha Leme ${ }^{* * *}$
}

Erick da Luz Scherf $* * * *$

* Recebido em: 13/09/2018

Aprovado em: 07/10/2018

** Doutor em Direito - UNISC, Mestre em Serviço Social -UFSC, Graduado em Direito pela UNESC. Professor Permanente do Programa de Mestrado em Direito da Universidade do Extremo Sul Catarinense. Líder do Grupo de pesquisa em Direito da Criança e do Adolescente e Políticas Públicas. Email: Ismael@ unesc.net

*** Doutoranda em Direito - UFSC, Mestra em Direito -UNISC, Graduada em Direito UNESC. Professora na Universidade do Vale do Itajaí (UNIVALI). Integrante do Grupo de Pesquisa "Direitos Humanos e Cidadania" da UNIVALI. Email: Luciana.rocha.leme@gmail. com

**** Acadêmico do Curso de Relações Internacionais da Universidade do Vale do Itajaí (UNIVALI). Integrante do Grupo de Pesquisa "Direitos Humanos e Cidadania" da UNIVALI. Monitor e bolsista do Grupo de Extensão "Direito Intergeracional e Transversalidade", também da UNIVALI. Email: erickscherf@gmail. com

\section{Abstract}

Human rights were traditionally approached in International Relations by the Schools of Realism and Liberalism. However, these two theoretical approaches to the analysis of these rights have proved to be insufficient, requiring a different reading of the reality of human rights in international society. This work considers the constructivist approach to analyze the effects of the Inter-American Human Rights System on disputes involving the Brazilian State, in order to identify why the Brazilian Supreme Court accepts or not the directions/standards formulated by the System in relation to the promotion and protection of human rights in the country. The theoretical basis of this work was the Constructivist Theory of International Relations, from Wendt and Hillebrecht. The method used was the inductive one, with bibliographical research. It was possible to recognize that Brazil did not comply with the determinations established by the Inter-American System in the case of "Gomes Lund v. Brazil" and "Herzog v. Brazil", but it followed the precepts of the American Convention by precluding the arrest of the unfaithful depositary. Therefore, it was identified that through theoretical constructivism it is possible to use more complex tools to analyze the way in which the States respond to the norms of human rights coming from the international society.

Keywords: International relations. Constructivism. Inter-American system of human rights. Brazilian Supreme Court. 


\section{Resumo}

Os direitos humanos são abordados tradicionalmente nas Relações Internacionais pelas escolas teóricas do Realismo e Liberalismo. No entanto, essas duas abordagens teóricas de análise destes direitos não são suficientes, exigindo uma leitura diferente da realidade dos direitos humanos na sociedade internacional. Assim sendo, este trabalho considera a abordagem construtivista para analisar os efeitos do Sistema Interamericano de Direitos Humanos em litígios envolvendo o Estado brasileiro, a fim de identificar por que o Supremo Tribunal Federal brasileiro acolhe ou não as orientações formuladas pelo Sistema em relação a promoção e proteção dos direitos humanos. A base teórica deste trabalho foi a Teoria Construtivista das Relações Internacionais, a partir de Wendt e Hillebrecht. O método utilizado foi o indutivo, com pesquisa bibliográfica. Foi possível reconhecer que o Brasil nem sempre cumpre as determinações estabelecidas pelo Sistema Interamericano, a exemplo do caso "Gomes Lund versus Brasil" e "Herzog versus Brasill", mas seguiu os preceitos da Convenção Americana ao impossibilitar a prisão do depositário infiel. Desta maneira, identificou-se que por meio do construtivismo teórico pôde-se lançar mão de ferramentas mais complexas para analisar a forma como os Estados respondem às normas de direitos humanos provenientes da sociedade internacional.

Palavras-chave: Relações internacionais. Construtivismo. Sistema Interamericano de Direitos Humanos. Supremo Tribunal Federal.

\section{INTRODUCTION}

Human rights is a quite contested concept that has generated a wide debate amongst scholars, lawyers, diplomats, activists and who else it might bring concern, over its legitimacy and efficacy. However, despite the innumerous and different opinions about the subject, one thing can hardly be denied, that human rights are here and they can't seem to go anywhere any time soon. As well stated by Mazower, "whether rhetoric or reality, human rights are a global phenomenon", and as being

1 MAZOWER, Mark. The strange triumph of human rights. The Historical Journal, [S.L.], v. 47, n. 2, p. 379-398, jun. 2004. Cambridge University Press (CUP). http://dx.doi.org/10.1017/ so they also bring impact to local scenarios, not being only a metaphysical experience but instead a phenomenon that represents material consequences to people's daily lives across the globe.

The human rights have pursued in history a path in which Norberto Bobbio divided in four different steps ${ }^{2}$. According to him, since the first appearance in the liberal political thought of the $17^{\text {th }}$ and $18^{\text {th }}$ century, the doctrine of the "rights of man" have advanced between conflicts and limitations. But these conflicts that the author enunciate are related to theoretical debates among the western (most European and North-American) scholars who alone developed a universal basis for human rights. From jusnaturalism to legal positivism, constructivism and beyond, human rights have always been an experience of the West. As defended by Grovogui, “[...] a valid theory of human rights must necessarily concede the Western origination of the concept and the ontological primacy of related Western institutions"

With that in account, it is acknowledgeable that even though Latin and South America have hardly participated on the formulation of the global human rights regime and that the history of the region is marked by authoritarianism and despotisms, the post-Cold War scenario represents a certain advancement on the talk of rights in the region. In the 1980s, the region sees the dismantling of its main military dictatorships in Argentina, Chile, Uruguay and Brazil ${ }^{5}$, which represents the opening of a discussion over the need of implementation of a certain core of rights due to the main violations of the basic liberties perpetrated by the dictatorial regimes that took place in the States of the region.

For that matter, it was instituted, in 1969, the Ameri-

s0018246x04003723. Available at: <https://www.mazower.com/ articles/HJ.pdf>. Access on: 15 feb. 2018. p. 379.

2 1) Constitutionalizing; 2) Progressive extension; 3) Universalization (mainly after World War II with the institutionalization of the United Nations and the formalization of the Universal Declaration of Human Rights); and 4) Specification of rights. BOBBIO, Norberto. Teoria geral da política: a filosofia política e as lições dos clássicos. Rio de Janeiro: Elsevier, 2000. p. 481-484.

3 BOBBIO, Norberto. Teoria geral da política: a filosofia política e as lições dos clássicos. Rio de Janeiro: Elsevier, 2000. p. 481.

4 GROVOGUI, Siba N. Mind, body, and gut::elements of a postcolonial buman rights discourse. 2006. Available at: < http:// digitalcommons.law. umaryland.edu $/ \mathrm{cgi} /$ viewcontent.cgi? article $=1002 \&$ context $=$ iclc papers>. Access on: 15 feb. 2018. p. 4.

5 PIOVESAN, Flávia. Direitos humanos e justiça internacional. 7. ed. São Paulo: Saraiva, 2017. p. 143-148. 
can Convention of Human Rights, signed in San José da Costa Rica, by only State-members of the Organization of American States $(\mathrm{OAS})^{6}$, with the intention to formalize the discussion of rights in the region and to stablish a regional mechanism for the protection and guarantee of the rights that have been abducted in the past.

In this sense, since the foundation of the Inter-American System of Human Rights (ISHR), by the consolidation of the American Convention of Human Rights in 1969, the System has worked towards an expansion of its jurisdiction and has developed other legal binding mechanisms besides the American Chart, according to Abramovich,

the ISHR, during the last decade, has influenced the process of internalization amongst the legal systems in various countries in Latin America. During this period, more countries have accepted the jurisdiction of the Inter-American court (such as Mexico and Brazil) $[\ldots]^{7}$.

As this process of "internalization" has increased throughout the years, the incorporation of international human rights law at the national level led to important institutional changes, therefore, it is important to study and analyze the impact of the system's jurisprudence over national legal apparatuses in the region, acknowledging the importance that the debate of human rights has acquired in the region.

Nonetheless, Brazil has been chosen to be the center of this study for some important reasons, besides being a great country in size and also in economy, it has been a regional leader over the decades and a potential key-actor in global affairs since the foundation of BRICS and the global financial crisis of 2008 and 2009. However, the consolidation of human rights in the country has been a struggle that the civil society, activists and some politicians have faced since the democratization of the Brazilian state in 1988, with the adoption of the new Constitution and the new model of government. Consonant to Pinheiro:

The present conjuncture of democratic consolidation, understood as continuous attention

6 PIOVESAN, Flávia. Direitos humanos e justiça internacional. 7. ed. São Paulo: Saraiva, 2017. p. 143-148.

7 ABRAMOVICH, Víctor. From massive violations to structural patterns: new approaches and classic tensions in the Inter-American human rights system. Sur, Rev. Int. Direitos Human., São Paulo, v. 6, n. 11, p. 6-39, Dec. 2009. Available at: <http://www.scielo.br/scielo. php?script $=$ sci_arttext\&pid=S1806-64452009000200002\&lng $=$ en \&nrm=iso $>$. Access on: 15 feb. 2018. p. 7. to a minimal list of prerequisites — such as freedom of opinion, expression, association, and organization, free and competitive elections, rotation in power, mechanisms of government accountability, the ability of social movements to participate openly in the public sphere, and State commitment to the protection of human rights constitutes a privileged moment to understand the persistence of authoritarian practices ${ }^{8}$.

The region of Latin and South America, specially Brazil, still preserves a part of the authoritarian spirit of the past, a ghost that haunts its democratic institutions and makes it difficult to implement the rights that lead to a fulfillment of the human dignity. So why countries like Brazil (even though being part of most of the treaties incorporated by the ISHR) sometimes refuse to accept the jurisprudence of the System in litigation involving cases in which they were condemned for violating human rights prerogatives? The answer to that is far from simple, but this research will try to find it through one of the many Constructivist strands of International Relations Theory, with particular interest in the works of Alexander Wendt ${ }^{9}$ and Courtney Hillebrecht ${ }^{10}$.

On that account, the first aim of the present article is to analyze the response of the Brazilian Supreme Court (Supremo Tribunal Federal, in Brazilian Portuguese) to the norms and jurisprudence of the Inter-American System of Human Rights and how they exercise influence or not in the institutional and juridical developments that take place in the Court. In order to do that, we have selected the cases of: 1) the human rights violations involving Brazil in the case: "Gomes Lund and others versus (v.) Brazill", and also in the recent case "Herzog and others v. Brazil", which have similar backgrounds and demands, in order to analyze whether they had or not influence on the Court's understandings; and 2) the decision of the Brazilian Supreme Court over the impossibility of imprisonment of the unfaithful depositary based on the American Convention of Human Rights. And as a secondary goal, we intend to identify the reasons why the Court has complied or not with

8 PINHEIRO, Paulo Sergio. Democratic consolidation and buman rights in Brazil. 1998. The Helen Kellogg Institute for International Studies. Available at: <https://kellogg.nd.edu/sites/default/files/ old_files/documents/256_0.pdf $>$. Access on: 15 feb. 2018. p. 6.

9 Wendt is Mershon Professor of International Security and Professor of Political Science at the Ohio State University.

10 Hillebrecht is an associate professor in the Department of Political Science at the University of Nebraska-Lincoln. Her research interests are in international relations, human rights and international law. 
the rulings or norms coming from the Inter-American System in the cases we have chosen to analyze.

The theoretical basis for this paper was the Constructivist Theory of International Relations developed in the works of Alexander Wendt and Courtney Hillebrecht, notwithstanding, the method used was the inductive one and the research mechanism was mainly based on bibliographic research.

The field of International Relations (IR) more specifically, "human rights" has been a quite new subject to be discussed by scholars and policy makers, taking into account that the diplomacy practitioners and international institutions, among other actors in foreign affairs, took a long time to consider this specific branch of rights into their debate agenda and international actions themselves. Principally in the period of the inter-world wars, the talk of rights seemed to not occupy the same position as it would on the post Second World War scenario, as accounted by Mazower:

Between the two world wars, talk of rights was far less common than it would subsequently become, and not even groups like the National Council for Civil Liberties or the French League for the Rights of Man were much concerned with human rights in the broad sense we have come today to associate with the term. Some far-sighted international lawyers formulated noble declarations and tried to pressure the League into adopting them: almost no one, at the time, took any notice ${ }^{11}$.

In this sense, even though human rights didn't necessary became a reality to all countries around the globe, they certainly incorporated, from 1945 and beyond, the debate agenda of many countries and institutions as well by scholars of different areas. Despite the fact that the study field of IR has not offered us with a specific and independent theory of human rights in international relations, it's acknowledgeable the works of different authors who attempted to study the phenomenon and the impact of human rights in international politics ${ }^{12}$.

11 MAZOWER, Mark. The strange triumph of human rights. The Historical Journal, [S.L.], v. 47, n. 2, p. 379-398, jun. 2004. Cambridge University Press (CUP). http://dx.doi.org/10.1017/ s0018246x04003723. Available at: <https://www.mazower.com/ articles/HJ.pdf>. Access on: 15 feb. 2018. p. 379-380.

12 See, among others: Vincent, R. J. Human rights and international relations. Cambridge, UK: Cambridge University Press, 1987; Lauren, Paul Gordon. The evolution of international human rights: visions seen. 2d ed. Pennsylvania Studies in Human Rights. Philadelphia: University of Pennsylvania Press, 2003; Michael Goodhart (ed), Human rights: Politics and Practice (Oxford: OUP, 2009). Henkin, Louis. The age of rights. New York: Columbia University Press, 1990.
Stephen M. Walt asked a very important question in the late 1990s regarding the state of IR theory at that time: "why should policy makers and practitioners care about the scholarly study of international affairs?"13. Well, according to him, the abstract world of theory shares an intimate relation with the world of policy, and we could not agree more. Especially when talking about the "scientific" theories of IR, such as the Structural Realism of Kenneth Waltz. The members of the Frankfurt School would say that such theories had an ultimate goal, which is to manipulate the external world ${ }^{14}$.

Thus, IR theories tried for a long time not only to make sense of the relations among States, but as well to shape world politics, serving for an instrumental purpose that is frequently hidden but is filled with interests that have direct impact in reality, by either supporting the status quo or transforming the world in its favor. Professor Herrera Flores, in a statement that is very coherent with what would later be known as the "Critical School" of Human Rights literature, professes that "theories constitute and reproduce practices and concrete forms of cultural and social production" ${ }^{\prime 15}$. This is what we will consider to be the Zeitgeist of this article.

We understand theory not only as a mere representation of the social world, but as well as a Funding Father of new worlds and new sets of beliefs. Therefore, when one takes into analysis the way scholars in IR have perceived the role of human rights in global affairs so far, it is possible to acknowledge that some of them have misshapen the talk of rights or human rights practices more broadly, so it could fit the expectations of IR theorists. It is an effort to manipulate different representations of reality, even though some deny to see it this way.

According to Dunne and Hanson, the study of human rights in IR can be divided into three theoretical approaches: Realism, Liberalism and Constructivism ${ }^{16}$.

13 WALT, Stephen M. International relations: one world, many theories. Foreign Policy, [S.L.], n. 110, p. 29-46, Spring 1998. JSTOR. http://dx.doi.org/10.2307/1149275. Available at: <https://www. jstor.org/stable/1149275?seq=1\#page_scan_tab_contents $>$. Access on: 13 sep. 2018. p. 29.

14 GEUSS, Raymond. The idea of a critical theory: Habermas and the Frankfurt School. Cambridge: Cambridge University Press, 1981. p. 55-95.

15 FLORES, Joaquín Herrera. La reinvención de los derechos bumanos. Andalucía: Atrapasueños, 2008. p. 116. Our translation.

16 DUNNE, Tim; HANSON, Marianne. Human rights in international relations. In: GOODHART, Michael (Ed.). Human rights: politics and practice. Oxford: Oxford University Press, 2009. p. 6176. 
Realists are completely skeptical about the existence or fulfillment of the human rights in global affairs, to them "human rights are very low on the list of national policy goals" 17 .

Differently, the liberalist approach defends the existence of moral universal principles inherent to life in society and to the achievement of human dignity ${ }^{18}$. Yet, both approaches are insufficient to the advancement of the talk of rights in IR. And they are because Realism neglects the global role that human rights have assumed in the contemporary international society, and Liberalism is revealed as normative as Realism when it accounts for the existence of universal binding principles that should regulate the conduct of states' actions and it doesn't account for change or discussions of these principles at all.

For that so, Constructivism has showed to be an important scape from the dilemma offered by the other two theories past presented. It differs from previous analysis of human rights in IR because it doesn't take human rights for granted or place them as universal unchangeable principles, instead, it sees them as social constructed.

Differing from liberalists, in his notable book entitled "Human Rights as Social Construction", Benjamin Gregg criticizes the conception of rights that is "valid independently of all institutions, and valid regardless of whether they are recognized by anyone [...]"19. Alternately, he provides a study that attempts to demonstrate that human rights are social constructed and they should be built upon local constructions of limited but expandable validity.

Differing then from scholars, the constructivists authors do not deny or try to impose a global validity of human rights, they simply argue that "there is no necessary tension between the interests of sovereign states and the moral principles associated with the promotion and protection of human rights" ${ }^{20}$. Taking this context

17 DUNNE, Tim; HANSON, Marianne. Human rights in international relations. In: GOODHART, Michael (Ed.). Human rights: politics and practice. Oxford: Oxford University Press, 2009. p. 61 76. p. 63.

18 CHARVET, John; NAY, Elisa Kaczynska. The liberal project and buman rights: the theory and practice of a new world order. Cambridge: Cambridge University Press, 2008. p. 59-78.

19 GREGG, Benjamin. Human rights as social construction. Cambridge: Cambridge University Press, 2011. p. 1.

20 DUNNE, Tim; HANSON, Marianne. Human rights in inter- into account, it is imperative to shine a new light upon the regional systems for the protection of human rights, as this paper is based primarily on the constructivist approach, it tries to analyze the role that the ISHR exercises in America, more specifically in Brazil, through a theoretical perspective that doesn't deny human rights or embrace them as universal unchanging values, but instead, provides a more broaden perspective which considers the main social processes involved in the creation, promotion and protection of human rights in different social contexts.

\section{Contextualization of the constructivist APPROACH TO HUMAN RIGHTS IN INTERNATIONAL RELATIONS}

This section intends primarily to draw an overlook over the core assumptions regarding the constructivist approach to human rights in order to provide an analytical basis for further investigation and analysis of the empirical cases chosen to be studied on the next division of this paper. Even though Alexander Wendt is the cornerstone that sustains this study ${ }^{21}$, other constructivist authors (mainly Courtney Hillebrecht) are also going to be taken into consideration because their work is able to help enriching the research and its objectives. It also analyzes briefly the impact of the Inter-American System's jurisdiction in the Brazilian legal order.

One might ask, how is it possible to have a Wendt's constructivist approach to human rights if the author himself never actually wrote anything about human rights on his major scholarly works? Well, it's acknowledgeable that Wendt didn't account for the subject in his seminal book entitled "Social Theory of International Politics" 22 , but if it wasn't for the theoretical efforts of him, we wouldn't be able to talk about human rights in IR theory at all.

national relations. In: GOODHART, Michael (Ed.). Human rights: politics and practice. Oxford: Oxford University Press, 2009. p. 6176. p. 64.

21 The reason we have chosen to work with Wendt is primarily due to the possibility that the works of the author open in IR theory to work with norms, values, ideas, identities, interest and other mechanisms which exercise influence in a society of States, also, previous theory lack on a social analysis of States' behavior in international relations because they consider the way the States act globally through a materialist and determinist view.

22 WENDT, Alexander. Social theory of international politics. New York: Cambridge University Press, 1999. 
While previous theories of International Relations (i.e. mainly liberalism and realism) focus on material factors such as power or trade, constructivism pays close attention to the impact of ideas in the international system, "although power is not irrelevant, constructivism emphasizes how ideas and identities are created, how they evolve, and how they shape the way states understand and respond to their situation" 23 .

And in doing so, constructivism accounts for change, in anarchy and in the way the States perceive each other within it. Wendt believes that anarchy does not possess only one logic of conflict and competition, but the opposite, it can embrace logics of conflict or cooperation, depending on what the states make of it (anarchy) ${ }^{24}$. Consequently, it is possible to imagine that the States might follow human rights principles if the social context they are embedded and participate as agents of change acknowledge values and principles as human rights to be important.

One of the prominent contributions to the author towards the role of human rights protection in the international scenario is the one regarding identities and interests. Wendt argues that is not possible for an actor to define its identity in an isolated context, "actors acquire identities — relatively stable, role-specific understandings and expectations about self — by participating in such collective meanings" ${ }^{25}$.

Thus, how is it possible to affirm that a State will necessarily consider invalidate the significance of human rights values prior to the participation of this State in relations with other actors which have themselves their own conceptions over this matter? Well, it is not. It is only possible to construct meanings over something participating collectively in the construction of these meanings: "each person has many identities linked to institutional roles, such as brother, son, teacher, and ci-

23 WALT, Stephen M. International relations: one world, many theories. Foreign Policy, [S.L.], n. 110, p. 29-46, Spring 1998. JSTOR. http://dx.doi.org/10.2307/1149275. Available at: < https://www. jstor.org/stable/1149275?seq=1\#page_scan_tab_contents $>$. Access on: 13 sep. 2018. p. 41.

24 WENDT, Alexander. Anarchy is what states make of it: the social construction of power politics. International Organization, [S.L], v. 46, n. 2, p. 391-425, jan. 1992. Available at: <http://www.jstor. org/stable/2706858>. Access on: 19 feb. 2018. p. 391-425.

25 WENDT, Alexander. Anarchy is what states make of it: the social construction of power politics. International Organization, [S.L], v. 46, n. 2, p. 391-425, jan. 1992. Available at: <http://www.jstor. org/stable/2706858>. Access on: 19 feb. 2018. p. 397. tizen. Similarly, a state may have multiple identities as "sovereign," "leader of the free world [...]"26 or human rights protector, but these identities can hardly be defined before looking into the social interaction and expectancy roles of the actors therefore analyzed.

Another important category to be taken into consideration is Wendt's notion of interest in international politics. Many authors of the realist theory of IR have argued that the major interest of States in the international system is to seek for survival, as if all of the others actors served as threats to the permanency of one State's security and livelihood, however, this view ignores the process of identity formulation and that identities are the basis for interest.

According to Wendt, "actors do not have a "portfolio" of interests that they carry around independent of social context; instead, they define their interests in the process of defining situations" 27 . And being so, a State can - depending on the social context and processes of identity formulation - define that the protection of human rights is indeed in its best interest, or it cannot, but is not up for us to say, but rather it is going to be a result of international interaction among states and other actors who are going to decide what is supposed to be in their ordre du jour or not.

Not only the social interaction among actors is responsible for defining identities and interests, institutions play a significant role in guiding the States' internalization of new identities and interests, notwithstanding, this process which the author called "institutionalization", does not happen from outside to inside, instead, it is a cognitive process that can't simply exist apart from the actors' ideas about the world, consonant to him:

An institution is a relatively stable set or "structure"
of identities and interests. Such structures are
often codified in formal rules and norms, but these
have motivational force only in virtue of actors'
socialization to and participation in collective
knowledge [...] As collective knowledge, they are
experienced as having an existence "over and above
the individuals who happen to embody them at the
moment." In this way, institutions come to confront

26 WENDT, Alexander. Anarchy is what states make of it: the social construction of power politics. International Organization, [S.L], v. 46, n. 2, p. 391-425, jan. 1992. Available at: <http://www.jstor. org/stable/2706858>. Access on: 19 feb. 2018. p. 398.

27 WENDT, Alexander. Anarchy is what states make of it: the social construction of power politics. International Organization, [S.L], v. 46, n. 2, p. 391-425, jan. 1992. Available at: <http://www.jstor. org/stable/2706858>. Access on: 19 feb. 2018. p. 398. 
individuals as more or less coercive social facts, but they are still a function of what actors collectively "know." Identities and such collective cognitions do not exist apart from each other; they are "mutually constitutive" ${ }^{\prime 28}$.

In this sense, we came to realize that if institutions such as international regimes do not comply with previous settled identities and interests of the actors involved in the social context they intend to "regulate", they are meant to fail. This is the opinion of Moravicsik relating to what is needed to create and effective international human rights regime. The scholar stablishes that domestic factors (to include State's and Civil Society's interests) are much relevant to the consolidation of an international regime for the protection and promotion of human rights:

[...] the most important factor defining the opportunities for and constraint on cooperation is the level of convergence of national preferences, which in turn reflect the demands of those domestic groups represented by the state (Burley, 1993a; Moravcsik, 1992). Effective international regimes are likely to emerge only where they have deep roots in the functional demands of groups in domestic and transnational society, as represented by the domestic political institutions that mediate between society and the state. Regimes foster compliance with international norms not by altering the external incentives facing a unitary state, but by altering the domestic incentives facing societal groups and politicians, thereby shifting the domestic coalitions that define state preferences ${ }^{29}$.

It is recognizable, thus, that international institutions for the protection of human rights should rise from the States' interests and also from demanding inner forces such as domestic actors as the organized civil society, NGOs and etc. But after the creation and establishment of such institutions, what would happen to them if it is no longer in a State's (or specific political group in power) interest to follow their recommendations and rules?

Well, an institution per se is a durable, long-term social construction, as stated by Hughes apud Keohane: "the only idea common to all usages of the term 'insti-

28 WENDT, Alexander. Anarchy is what states make of it: the social construction of power politics. International Organization, [S.L], v. 46, n. 2, p. 391-425, jan. 1992. Available at: <http://www.jstor. org/stable/2706858 >. Access on: 19 feb. 2018. p. 399.

29 MORAVCSIK, Andrew. Explaining international human rights regimes: liberal theory and western Europe. European Journal of International Relations, London, Thousand Oaks, CA and New Dheli, v. 1, n. 2, p. 157-189, jan. 1995. Available at: <https://www. princeton.edu/ amoravcs/library/explain.pdf $>$. Access on: 19 feb. 2018. p. 158. tution' is that of some sort of establishment of relative permanence of a distinctly social sort" ${ }^{\prime 30}$. Consequently, international institutions such as an international regime for the protection of human rights shouldn't be left to the willing of a single deviant actor once they were stablished by an ongoing pattern of practices and reciprocity among the social actors involved in this institutionalized context.

However, even though being aware of this and being embedded in these institutionalized environments, some States fight against compliance when relating to International Human Rights Courts (IHRCs), but why do they do so? The answer to this question can be blurred, but we will try to clarify as much as possible through the constructivists approaches of Hillebrecht ${ }^{31}$. In a sense that the author is responsible for a large theoretical and empirical work in which she analyzes countries and their acceptation or denial of human rights recommendations from regional systems for the protection of human rights, including the Inter-American one.

One of the greatest challenges for regional mechanisms for the protection of human rights (especially the Inter-American System) is compliance. According to Mazzuoli, one complex question is the one related to the sentences propelled by the Inter-American Court, as the author stated, the ISHR has yet to achieve an effective system for the execution of the Court's verdicts, he affirms that the great problem that exists with respect to the full compliance of the obligations imposed on States by the Inter-American Court is not in the indemnity part of the sentence, but in the difficulty of internally performing the duties of investigating and punishing those responsible for human rights violations ${ }^{32}$.

30 KEOHANE, Robert O. International institutions: two approaches. International Studies Quarterly, [S.L], v. 4, n. 32, p. 379-396, dec. 1988. Available at: <https://edisciplinas.usp.br/pluginfile. $\mathrm{php} / 161137 /$ mod_resource/content/1/Keohane 1988 - International Institutions - two approaches.pdf>. Access on: 19 feb. 2018. p. 382.

31 HILLEBRECHT, C. Rethinking compliance: the challenges and prospects of measuring compliance with international human rights tribunals. Journal of Human Rights Practice, [S.1.], v. 1, n. 3, p. 362-379, 16 set. 2009. Available at: <https://academic.oup.com/ jhrp/article-abstract/1/3/362/2188667>. Access on: 19 feb. 2018; HILLEBRECHT, Courtney. The domestic mechanisms of compliance with international human rights law: case studies from the inter-american human rights system. Human Rights Quarterly, [S.l.], v. 34, n. 4, p. 959-985, 2012. Johns Hopkins University Press. http:// dx.doi.org/10.1353/hrq.2012.0069. Available at: <https://muse. jhu.edu/article/489370/pdf>. Access on: 6 mar. 2018.

32 MAZZUOLI, Valério de Oliveira. Curso de direito internacional 
Despite the difficulty in implementing the human rights recommendations in different national contexts in America, the Court and the entire System itself (including the OAS), play an important role often devalued, consonant to Piovesan, the Brazilian experience reveals that international action has also aided the publicity of human rights violations, which poses the risk of political and moral embarrassment to the violating State, and in this sense, it emerges as a significant factor for the protection of human rights ${ }^{33}$.

As stated as well by Hillebrecht,

[...] the Inter-American tribunals rely on state reporting, site-visits and updates from activists and victims and monitor compliance with their own mandates. Their main tool to foster compliance is making as much compliance information public as possible $^{34}$.

However, Hillebrecht stresses that although the reporting efforts by the System are important advancements into making governments' human rights obligations more transparent,

the political organs of the OAS have been very reluctant to participate in overseeing or facilitating compliance with the human rights institutions, which has dampened the impact of the tribunals on the states' human rights practices ${ }^{35}$.

It is important to point out, before continuing, that the constructivism of Hillebrecht differs in object and method from the one of Wendt's, "while the constructivism notion of norms, legitimacy, and social processes in international relations accounts are usually applied to inter-state processes, Hillebretcht's focus is on political processes within the state" ${ }^{\text {36. It }}$ is due to this reason that

público. 10. ed. São Paulo: Revista dos Tribunais, 2016. p. 993-996.

33 PIOVESAN, Flávia. Direitos bumanos e o direito constitucional internacional. 15. ed. São Paulo: Saraiva, 2015. p. 444-445.

34 HILLEBRECHT, C. Rethinking compliance: the challenges and prospects of measuring compliance with international human rights tribunals. Journal of Human Rights Practice, [S.L.], v. 1, n. 3, p. 362-379, 16 sep. 2009. Available at: <https://academic.oup.com/ jhrp/article-abstract/1/3/362/2188667>. Access on: 19 feb. 2018. p. 364.

35 HILLEBRECHT, C. Rethinking compliance: the challenges and prospects of measuring compliance with international human rights tribunals. Journal of Human Rights Practice, [S.L.], v. 1, n. 3, p. 362-379, 16 sep. 2009. Available at: <https://academic.oup.com/ jhrp/article-abstract/1/3/362/2188667>. Access on: 19 feb. 2018. p. 364.

36 BATES, E. S. Sophisticated constructivism in human rights compliance theory. European Journal of International Law, [S.1.], v. 25, n. 4, p. 1-20, 1 nov. 2014. Available at: <https://doi.org/10.1093/ ejil/chu084>. Access on: 19 feb. 2018. p. 8. she was chosen to help achieving the goals of this study, because Wendt's constructivism does not offer the necessary tools to study the domestic institutions that are indeed crucial to compliance.

There are no easy answers to why the States are reluctant in complying with human rights implementation measures coming from IHRCs and what could be done about it, but in order to try to shine a light in the path to these answers, before we must analyze what current mechanisms of compliance are available in the Inter-American System. Professor Hillebrecht states that The Inter-American tribunals usually offer a broad and diverse set of recommendations and requirements in their rulings. The main supports for the System's sentences are represented in Table 1:

Table 1 - The four Hillebrecht categories of obligations set by the Inter-American Tribunals ${ }^{37}$.

\begin{tabular}{l} 
1. Payment of reparations to the victims and \\
their families; \\
\hline $\begin{array}{l}\text { 2. states' recognition of their responsibility } \\
\text { for the violation and honoring the victims } \\
\text { through symbolic political measures; }\end{array}$ \\
3. providing justice at the state level, including \\
retrials and accountability for individual \\
perpetrators; \\
4. and measures of non-repetition that will \\
prevent the same abuses from happening in \\
the future.
\end{tabular}

Source: Hillebrecht (2009), table elaborated by the authors.

In Brazil, the doctrine adopted by the Supreme Court relating to the adequacy of the national legal order to the norms and recommendations in human rights treaties ratified and homologated by the Brazilian Republic is called "control of conventionality". Through the use of this doctrine, Brazilian jurists are able to adequate the country's legislation to both international treaties of human rights, and the requirements and re-

37 Table elaborated by the authors, content found in: HILLEBRECHT, C. Rethinking compliance: the challenges and prospects of measuring compliance with international human rights tribunals. Journal of Human Rights Practice, [S.1.], v. 1, n. 3, p. 362-379, 16 sep. 2009. Available at: <https://academic.oup.com/jhrp/article-abstract/1/3/362/2188667>. Access on: 19 feb. 2018. p. 365. 
commendations of the Inter-American Commission and the Inter-American Court ${ }^{38}$ :

the control of conventionality is a tool used in order to achieve the material compatibility between the normative acts of the signatory States and the provisions laid down in an international treaty $[\ldots]^{39}$.

The Constitutional Amendment No 45/2004, which added Paragraph $3^{\text {rd }}$ to Art. (5) of the Brazilian Federal Constitution has brought the possibility of international human rights treaties approved with a qualified quorum to pass from a materially constitutional status to the (formal) condition of treaties equivalent to constitutional amendments ${ }^{40}$. However, this mechanism has hardly ever been used and the only international treaty incorporated to the constitutional level was the Convention on the Rights of Persons with Disabilities (CRPD) (Decree 6.949/2009).

Therefore, even though the country has national institutional mechanisms to account for changes, why Brazil hardly ever changes its legislation to be in conformation with international human rights rules and moreover the Inter-American System's resolutions? Hillebrecht states that some measures elaborated by these regional human rights tribunals are costlier than others:

$[\ldots]$ she finds that states might be more willing to incur financial or symbolic costs than to reform legislation or conduct new trials $[. .$.$] some remedies$ may be more politically costly than others to implement. States which are asked to implement remedies of non-repetition or to conduct retrials will face higher political stakes than those required merely to provide compensation, and cover costs and expenses ${ }^{41}$.

This relies also in the fact that the OAS itself does not offer mechanisms to enforce compliance, without any specific organ or measure designed to impose sanc-

38 MAZZUOLI, Valerio de Oliveira. O controle jurisdicional da convencionalidade das leis. 2. ed. São Paulo: Revista dos Tribunais, 2011. p. 73-137.

39 SCHÄFER, Gilberto et al. Os controles de convencionalidade tradicional e interamericano: institutos distintos ou duas faces da mesma moeda?. Revista de Direito Internacional, Brasília, v. 14, n. 3, p. 216-242, dec. 2017. Available at: <https://www.publicacoes.uniceub.br/rdi/article/view/4811>. Access on: 4 oct. 2018. p. 218.

40 MAZZUOLI, Valerio de Oliveira. O controle jurisdicional da convencionalidade das leis. 2. ed. São Paulo: Revista dos Tribunais, 2011. p. 50-68.

41 BATES, E. S. Sophisticated constructivism in human rights compliance theory. European Journal of International Law, [S.I.], v. 25, n. 4, p. 1-20, 1 nov. 2014. Available at: <https://doi.org/10.1093/ ejil/chu084>. Access on: 19 feb. 2018. p. 9-10. tions to state-members in cases they were charged and condemned for human rights violations it becomes really hard for the Inter-American System to assure that the Sates will comply with its ruling.

These are some important factors that the constructivist approach takes into consideration when measuring States' compliance to International Human Rights Systems' rulings, considering both the domestic (such as internal political struggle or a State's national institutions) and the international political context (such as the inertia of OAS, as above mentioned) instead of blaming the anarchy of the international system or the way in which one State is constituted (mainly if it is a liberal democracy or not) as main factors to determine whether a country is able to protect and promote human rights or not ${ }^{42}$, hence, constructivism from Wendt to Hillebrecht allows us to go deeper inside the problem of human rights implementation, differently from the traditional approach to human rights in IR theory.

\section{BRAZIL UNDER THE RULE OF THE INTER- AMERICAN SYSTEM - SEEING THROUGH CONSTRUCTIVIST LENSES}

This division is responsible for bringing to light some cases in which the Brazilian Supreme Court has

42 Neorealists such as Waltz would point out the cause of noncompliance of States to Human Rights Courts to the "nature" of the international system: anarchy, not simply the non-existence of a global political binding power, but specially in the rules in which he believes to be present in this anarchical environment, to him "anarchy shapes the politics of international systems" (DEUDNEY, 2011, p. 17), therefore, if a change doesn't happen in the structure of anarchy, the world politics tends to preserve some basic rules, as survival being the States' first goal in the international system, and in doing so, Waltz neglects any possibility of change in State's behavior. The liberals choose another path, yet they tend to make a similar mistake. Rawls, for an example, accounts that "[...] only liberal democratic governments are effective in protecting even those human rights specified by the Law of Peoples" (RAWLS, 1999, p. 79), in this sense, if we were to analyze through Rawls' liberal conception, the reason to comply or not with human rights recommendations would lie upon a State's particular constitution, which is completely outrageous, considering that some considered "liberal democratic States", nowadays, do not comply with International Human Rights Courts, as the USA, that hasn't signed up the American Convention or either taken part in any mechanism for external control of States' practices towards its population such as the Inter-American System. That's the reason why constructivism deepens the understanding over compliance to human rights in the international system, because it takes both changes in the international society and internal struggles into consideration when measuring compliance. 
once showed compliance with the Inter-American System's resolutions and once did not. The theoretical background that is going to be used in order to help us explain such different moves from the Court before the jurisprudence and norms of the System was expatiated in the former section, and now, it will be applied to different empirical cases: 1) the human rights violations involving Brazil in the case: "Gomes Lund and others versus Brazil", and also in the recent case "Herzog and others versus Brazil", which have similar backgrounds and demands; and 2) the decision of the Brazilian Supreme Court over the impossibility of imprisonment of the unfaithful depositary based on the American Convention of Human Rights.

\subsection{Contextualization and impacts from "Gomes Lund and others versus Brazil" and "Herzog versus Brazil" in the Brazilian Supreme Court}

In the case entitled "Gomes Lund and other versus Brazil", the Inter-American Court, in 2010, condemned Brazil due to the disappearance of members of the Araguaia guerrilla, which happened during military operations developed in 1970's in the country ${ }^{43}$. But before analyzing the jurisprudence of the Court regarding the case itself, it's necessary to draw a quick overview of the social-historical background that those events of forced disappearance took place.

The scenario in which Brazil was a part of in the time of the events of the Araguaia guerrilla was the Cold War one, that affected both global, regional, and local power structures. As well stated by Leffler and Painter, "for forty-five years the Cold War was at the center of world politics" tween the two super powers at that time (United States and Soviet Union), caused impacts in different levels inside the States of the international society, "the Cold War also shaped the foreign policy and domestic politics of most other nations around the globe. Few countries, in fact, escaped its influence" ${ }^{\prime 4}$. In this sense, it is

43 PIOVESAN, Flávia. Direitos bumanos e o direito constitucional internacional. 15. ed. São Paulo: Saraiva, 2015. p. 448-449.

44 LEFFLER, Melvyn P.; PAINTER, David S. Introduction. In: (Ed.). Origins of the cold war: an international history. 2. ed. New York; Abingdon: Routledge, 1994. p. 1-12. p. 1.

45 LEFFLER, Melvyn P.; PAINTER, David S. Introduction. In: (Ed.). Origins of the cold war: an international history. 2. ed. New York; Abingdon: Routledge, 1994. p. 1-12. p. 1. possible to acknowledge that it had a great influence in Brazil's politics and economy at that time.

In Latin America, the principal characteristics of the post-Second War era was the victory the Allies (i.e, democracy over fascism), almost all of the Latin American countries entered the North-American umbrella,

as the nature of the postwar international order and the hegemonic position of the US within it became clear, the dominant groups in Latin America, including the military $[\ldots]$, recognized the need to make some necessary political adjustments ${ }^{46}$.

The victory of the United States and its Allies not only represented the end of totalitarianism in Europe, it represented the sunrise of the North-American ideals of capitalism, liberalism and democracy, that were to be applied with no necessary prescription across the globe, including Latin America.

At the same time as the Latin American countries were seeking to adopt a North-American model of development, based upon a liberal economy, there was, according to Bethell and Roxborough (1994), an increasing movement of pressures coming from below in these societies, especially from the urban working class that started to grow a lot in this period, and along with the working class expansion in Brazil there was a widespread expansion of union membership, in Brazil, about 351,000 workers joined working unions in $1940^{47}$.

In this sense, once a considerable part of the population were workers at the time, the State was supposed to aim the necessities of this new uprising class, but it did not (thanks to the great influence of the Latin American elites), what caused the emergence of several communist revolutionary parties across Latin America and also in Brazil more specifically, that claimed for the necessity of social reforms that would attend the needs of the working class:

The commitment of Latin American elites to
formal, liberal democracy of the kind espoused by
the United States, in so far as it existed in other than
a purely rhetorical form, by no means implied an
acceptance of wide-ranging social reform and the

46 BETHELL, Leslie; ROXBOROUGH, Ian. The impact of the cold war on Latin America. In: LEFFLER, Melvyn P.; PAINTER, David S. (Ed.). Origins of the cold war: an international history. 2. ed. New York; Abingdon: Routledge, 1994. p. 299-316. p. 302-303. 47 BETHELL, Leslie; ROXBOROUGH, Ian. The impact of the cold war on Latin America. In: LEFFLER, Melvyn P.; PAINTER, David S. (Ed.). Origins of the cold war: an international history. 2. ed. New York; Abingdon: Routledge, 1994. p. 299-316. 
recognition of organized labor as a major political $\operatorname{actor}^{48}$.

However, years later in Brazil (1961-1964), the former president João Goulart (Jango) started to develop a government aimed at promoting social justice and national sovereignty. His policy of valorizing labor rights, defending basic reforms - agrarian, tax, urban, educational and electoral - and independence in foreign relations, displeased the interests of the Brazilian bourgeoisie associated with the imperialist capital and the interests of the United States in the region ${ }^{49}$. To stop Jango's reforms, several Brazilian social and military sectors performed, in 1964, a coup d'etat. Consonant to Lara and Silva,

the civil-military coup was the capitalist resistance to the possibilities of reforms and social advances. Through violence, the reactionary sectors acted with arrests of leaderships, torture, assassinations, expulsion of leftist leaders of the country and intervention in unions ${ }^{50}$.

In sum, this was the social-historical context that preceded the Araguaia Guerrilla (ArGr).

During the experience of the dictatorship (19641985), the ruling military power in Brazil had to face several revolutionary movements that were strongly against the succumbence of basic civil liberties and also the social rights that Jango had promised to guarantee. One of these movements was the ArGr, inspired by the popular and civil war that led to the Chinese Revolution of 1949, the guerrilla aimed to fight against the military dictatorship and foment, from the field (countryside), a popular democracy in Brazil ${ }^{51}$.

48 BETHELL, Leslie; ROXBOROUGH, Ian. The impact of the cold war on Latin America. In: LEFFLER, Melvyn P.; PAINTER, David S. (Ed.). Origins of the cold war: an international history. 2. ed. New York; Abingdon: Routledge, 1994. p. 299-316. p. 308.

49 LARA, Ricardo; SILVA, Mauri Antônio da. A ditadura civilmilitar de 1964: os impactos de longa duração nos direitos trabalhistas e sociais no Brasil. Serviço Social \& Sociedade, [S.L.], n. 122, p. 275-293, jun. 2015. Available at: <http://www.scielo.br/pdf/sssoc/ n122/0101-6628-sssoc-122-0275.pdf>. Access on: 6 mar. 2018. p. 275-293.

50 LARA, Ricardo; SILVA, Mauri Antônio da. A ditadura civilmilitar de 1964: os impactos de longa duração nos direitos trabalhistas e sociais no Brasil. Serviço Social \& Sociedade, [S.L.], n. 122, p. 275-293, jun. 2015. Available at: <http://www.scielo.br/pdf/sssoc/ n122/0101-6628-sssoc-122-0275.pdf > . Access on: 6 mar. 2018. p. 277-278. Our translation.

51 PEIXOTO, Rodrigo Corrêa Diniz. Memória social da Guerrilha do Araguaia e da guerra que veio depois. Bol. Mus. Para. Emílio Goeldi. Cienc. Hum., Belém, v. 6, n. 3, p. 479-499, dec. 2011. Available at: <https://goo.gl/kheLYs>. Access on: 6 mar. 2018. p. 479-499.
The ArGr took place in the southeastern regions of Pará and north of the former state of Goiás (now Tocantins), also covering lands of Maranhão, in the area known as 'Bico do Papagaio'. In this region there were supposed to exist, for the PCdoB (Communist Party of Brazil) communists, the elements considered necessary for the development of guerrilla warfare such as new lands in a recent occupation process, social conflicts over land tenure; absence of the State, failing to fulfill its basic functions and an area of difficult access because of the dense forest ${ }^{52}$. The Guerrilla occurred in the mid-1960s, when the first PCdoB members arrived in the region, and in 1974, when the last guerrillas were hunted and killed by the military that were trained to fight the guerrillas and ordered to not take prisoners. Executions, trace removal and torture are in the reports collected, as well as in the existing literature on guerrilla warfare ${ }^{53}$.

The Inter-American Court in its denunciation alleged the responsibility of the Brazilian State for the arbitrary detention, torture and forced disappearance of 70 persons, among members of the $\mathrm{PCdoB}$ and farmers, as a result of actions taken by the Army in the region between 1972 and 1975. In addition, the Court requested that Brazil was to be held responsible for not investigating such violations, with the purpose of judging and punishing those responsible, with the support of the national Law no 6,683 of August 28, 1979, the often-called Amnesty Law ${ }^{54}$.

The results were that the only attempt to initiate an internal criminal action was judicially rejected, based on the Brazilian Amnesty Law and by time limitation procedures, thus violating the judgment of the Court in the Lund case. The representatives point out that the State,

52 NASCIMENTO, Durbens Martins. A Guerrilha do Araguaia: paulistas e militares na Amazônia. 2000. 199 f. Dissertation (Masters) - Planning of Development Course, Universidade Federal do Pará, Belém, 2000. Available at: <http://www.repositorio.ufpa.br/ jspui/bitstream/2011/2458/1/Dissertacao_GuerrilhaAraguaiaPaulistas.pdf>. Access on: 6 mar. 2018. p. 49-60.

53 PEIXOTO, Rodrigo Corrêa Diniz. Memória social da Guerrilha do Araguaia e da guerra que veio depois. Bol. Mus. Para. Emílio Goeldi. Cienc. Hum., Belém, v. 6, n. 3, p. 479-499, dec. 2011. Available at: <https://goo.gl/kheLYs>. Access on: 6 mar. 2018. p. 479-499.

54 CEIA, Eleonora Mesquita. A jurisprudência da Corte Interamericana de Direitos Humanos e o desenvolvimento da proteção dos direitos humanos no Brasil. R. EMERJ, Rio de Janeiro, v. 16, n. 61, p. 113-152, jan. 2013. Available at: <http://www.emerj.tjrj. jus.br/revistaemerj_online/edicoes/revista61/revista61_113.pdf $>$. Access on: 6 mar. 2018. p. 124-133. 
in its December 2011 report, refers only to actions of a civil and administrative measures performed within the domestic scope, but not to any of a criminal nature, as determined by the Court in its judgment ${ }^{55}$. In this sense, the real perpetrators of the actions of human rights violations in the Araguaia Guerrilla are yet to face justice.

This part of the sentence (individual persecution) in the Gomes Lund case, falls into the third category of obligations set by the Inter-American System according to Hillebrecht's classification: 3) providing justice at the state level, including retrials and accountability for individual perpetrators (see Table 1). When the sentence involves this category, it becomes really hard to find cases of compliance due to two main reasons: struggles in internal political institutions and fear of threatening at the individual level.

In the domestic sphere, the Brazilian Federal Supreme Court judged on April 29, 2010, the Action for Non-compliance with Basic Precept (ADPF) ${ }^{56} \mathrm{n}^{\mathrm{o}} 1531$, in which the Court considered the Law no 6,683 of 1979 (Amnesty Law) as being constitutional, recognizing not only its constitutionality, but the validity of its effects ${ }^{57}$. Here, the Brazilian Supreme Court did not consider the dispositions set in the sentence of the case "Gomes Lund and others", which considered, seven months before the ADPF, that the Brazilian Amnesty Law was not valid in face of the obligations set by the international human rights law ${ }^{58}$, even though the Executive Power had already

55 CEIA, Eleonora Mesquita. A jurisprudência da Corte Interamericana de Direitos Humanos e o desenvolvimento da proteção dos direitos humanos no Brasil. R. EMERJ, Rio de Janeiro, v. 16, n. 61, p. 113-152, jan. 2013. Available at: <http://www.emerj.tjrj. jus.br/revistaemerj_online/edicoes/revista61/revista61_113.pdf $>$. Access on: 6 mar. 2018. p. 124-133.

56 In Brazilian Portuguese, "Arguição de Descumprimento de Preceito Fundamental (ADPF)". Its purpose is to prevent or remedy injuries to a fundamental precept deriving from the Constitution, resulting from any act (or omission) of the Public Power.

57 SILVA, Carla Ribeiro Volpini; WANDERLEY JUNIOR, Bruno. A responsabilidade internacional do Brasil em face do controle de convencionalidade em sede de direitos humanos: conflito de interpretação entre a jurisdição da Corte Interamericana de Direitos Humanos e o Supremo Tribunal Federal quanto a Lei de anistia. Revista de Direito Internacional, [S.L.], v. 12, n. 2, p.611-629, 31 Dec. 2015. Centro de Ensino Unificado de Brasília. Available: <http://dx.doi. org/10.5102/rdi.v12i2.3699>. Access on: 04 Oct. 2018. p. 613.

58 SILVA, Carla Ribeiro Volpini; WANDERLEY JUNIOR, Bruno. A responsabilidade internacional do Brasil em face do controle de convencionalidade em sede de direitos humanos: conflito de interpretação entre a jurisdição da Corte Interamericana de Direitos Humanos e o Supremo Tribunal Federal quanto a Lei de anistia. Re-
[...] acknowledged its responsibility for crimes committed in the repression of the Araguaia Guerrilla [...] through the enactment of the Law $n^{\circ}$ $9.140 / 95$, in which the Brazilian State acknowledged the deaths and provided for the payment of compensation to victims' relatives ${ }^{59}$.

On that spirit, more recently, the Inter-American Commission on Human Rights (CIDH) has also received other petitions regarding crimes committed by State agents during the military rule in Brazil. Nonetheless, on July 10, 2009, the Inter-American Commission on Human Rights was presented with a petition by the Center for Justice and International Law (CEJIL) and other several national non-governmental organizations based in Brazil, in which they alleged the international responsibility of the country for the arbitrary arrest, torture and death of the journalist Vladimir Herzog, which took place in an army unit on October 25, 1975, and by the continuous impunity of the facts, due especially to the Amnesty Law promulgated during the Brazilian military dictatorship, as above commented ${ }^{60}$.

A settlement between Brazil and the petitioners was not reached in time, thus, it became the responsibility of the Inter-American Commission to elaborate a report setting forth the facts and stating the conclusions regarding the case, as stated in the article 50 of the American Convention on Human Rights ${ }^{61}$. Therefore, in 2015, the CIDH decided that the demands by the petitioners were valid and the Brazilian State was indeed to be held accountable for the death of Vladimir Herzog, and one of its recommendations required Brazil to

adopt all the necessary measures to guarantee that

vista de Direito Internacional, Brasília, v. 12, n. 2, p. 611-629, 31 dec. 2015. Available: <http://dx.doi.org/10.5102/rdi.v12i2.3699>. Access on: 4 oct. 2018. p. 613.

59 BRAGATO, Fernanda Frizzo; COUTINHO, Isabella Maraschin. A efetivação do direito à memória e à verdade no contexto brasileiro: o julgamento do caso Julia Gomes Lund pela corte interamericana de direitos humanos. Revista de Direito Internacional, Brasília, v. 9, n. 1, p. 125-142, 23 jul. 2012. Available at: <http:// dx.doi.org/10.5102/rdi.v9i1.1594>. Access on: 4 oct. 2018. p. 135. Our translation. Original: "[...] reconheceu a sua responsabilidade pelos crimes ocorridos na repressão à Guerrilha do Araguaia [...] na promulgação da Lei n. 9.140/95, na qual reconheceu as mortes e dispôs sobre o pagamento de indenizações aos familiars das vítimas, e na audiência pública realizada perante a Corte IDH".

60 CIDH. Relatório $n^{\circ} 71 / 15$, Caso 12.879: relatório de mérito: Vladimir Herzog e outros Brasil. 2015. Available at: < http://www. oas.org/es/cidh/decisiones/corte/2016/12879FondoPt.pdf>. Access on: 4 oct. 2018. p. 1-2.

61 CIDH. American Convention on Human Rights. 1969. Available at: $<$ https://www.cidh.oas.org/basicos/english/basic3.american $\% 20$ convention.htm> Access on: 4 oct. 2018. 
the Law $\mathrm{n}^{\circ}$ 6,683/79 (Amnesty Law) and other provisions of criminal law [...] do not continue to present an obstacle to the criminal prosecution of serious human rights violations ${ }^{62}$.

However, again, just like in the Gomes Lund litigation, Brazil did not follow the Inter-American Commission's recommendations and failed to investigate and sanction those responsible for the torturing and assassination of the journalist Herzog. Therefore, on July fourth, 2018, the Inter-American Court of Human Rights condemned the Brazilian State, as it follows:

\begin{abstract}
The Inter-American Court concluded that, due to the lack of investigation, as well as of prosecution and punishment of those responsible for the torture and murder of Vladimir Herzog, committed in a systematic and generalized context of attacks against the civilian population, Brazil violated the rights to the judicial guarantees and the judicial protection of Zora, Clarice, André and Ivo Herzog, established in Articles 8 and 25 of the American Convention, in relation to the Inter-American Convention to Prevent and Punish Torture. Likewise, the Court concluded that Brazil failed to comply with its obligation to adapt its domestic law to the Convention by virtue of the application of the Amnesty Law and other exemptions from liability prohibited by international law, thus failing to comply with Article 2 of the American Convention $^{63}$.
\end{abstract}

The country has one year to report to the Court the developments regarding the implementation of the measures set by the sentence, however, thus far the Brazilian Supreme Court was not called up again to rule on

62 CORTE INTERAMERICANA DE DERECHOS HUMANOS. Caso Herzog y otros vs. Brasil: sentencia de 15 de marzo de 2018. 2018. Available at: <http://www.corteidh.or.cr/docs/casos/ articulos/seriec_353_esp.pdf $>$. Access on: 4 oct. 2018. p. 3. Our translation. Original: "adoptar todas las medidas necesarias para garantizar que la Ley No 6.683/79 (Ley de Amnistía) y otras disposiciones del derecho penal [...] no sigan presentando un obstáculo para la persecución penal de graves violaciones de derechos humanos".

63 CORTE INTERAMERICANA DE DERECHOS HUMANOS. Brasil es responsable por no investigar crimen de lesa bumanidad cometido contra el periodista Vladimir Herzog. 2018. Press Release. Available at: <http://www.corteidh.or.cr/docs/comunicados/cp_25_18. pdf $>$. Access on: 4 oct. 2018. p. 2. Our translation. Original: " $L a$ Corte Interamericana concluyó que, debido a la falta de investigación, así como de juzgamiento y sanción de los responsables de la tortura y asesinato de Vladimir Herzog cometidos en un contexto sistemático y generalizado de ataques a la población civil, Brasil violó los derechos a las garantías judiciales y a la protección judicial de Zora, Clarice, André e Ivo Herzog, establecidos en los articulos 8 y 25 de la Convención Americana, en relación con la Convención Interamericana para Preveniry Sancionar la Tortura. Asimismo, la Corte concluyó que Brasil incumplió su obligación de adecuar su derecho interno a la Convención en virtud de la aplicación de la Ley de Amnistía y de otras eximentes de responsabilidad prohibidas por el derecho internacional, incumpliendo así en artículo 2 de la Convención Americana". the constitutionality of the Amnesty Law or other legal instruments that impose a resistance to the investigation of Herzog's assassination. Here, the accounts of professor Hillebrecht appear to be helpful once again, according to her, domestic and international political institutions and civil society actors are cornerstones when talking about implementation of the remedies set by the Inter-American Court ${ }^{64}$.

In both cases here analyzed, "Gomes Lund v. Brazil" and "Herzog v. Brazil", transnational activism towards the realization of human rights was one the most important tools to faster the publicity and admission of such cases in the Inter-American System, in a sense that

[...] it can be affirmed that the scope of this new type of activism has a broad potentiality of effectiveness, since, in addition to remedying individual abuses, they facilitate the (re)politicization and (re)legalization of human rights policies ${ }^{65}$.

Alongside the national and transnational activism, the enforceability of the sentences coming from the Inter-American Court of Human Rights should also be a product of judicial activism, as stated by Resende:

despite the art. 68.2 of the Pact of San José of Costa Rica refers only to the pecuniary penalty, the extra-pecuniary part of the judgments of the InterAmerican Court of Human Rights may be executed within the scope of the Brazilian Judiciary $[. . .]^{66}$.

On this account, it is the duty of the Brazilian Supreme Court, as the ultimate institution to exercise the control of conventionality, to rule in favor of the dispositions found in the sentences and recommendations

64 BATES, E. S. Sophisticated constructivism in human rights compliance theory. European Journal of International Law, [S.1.], v. 25, n. 4, p. 1-20, 1 nov. 2014. Available at: <https://doi.org/10.1093/ ejil/chu084>. Access on: 19 feb. 2018. p. 8.

65 ALVES, Lucélia de Sena; LIMA, Renata Mantovani de. A efetividade do ativismo jurídico transnacional no sistema interamericano de direitos humanos: uma análise a partir de casos contra o Brasil. Revista de Direito Internacional. Brasília, v. 10, n. 2, p. 238-249, 4 jan. 2014. Available at: <http://dx.doi.org/10.5102/rdi.v10i2.2558>. Access on: 4 oct. 2018. p. 240. Our translation. Original: “[...] pode-se afirmar que o alcance desse novo tipo de ativismo possui uma potencialidade ampla de efetivação, uma vez que, além de remediar abusos individuais, propiciam a (re)politização e (re)legalização das políticas relativas aos direitos bumanos". 66 RESENDE, Augusto. A executividade das sentenças da Corte Interamericana de Direitos Humanos no Brasil. Revista de Direito Internacional, Brasília, v. 10, n. 2, p. 227-236, 4 jan. 2014. Available at: <http://dx.doi.org/10.5102/rdi.v10i2.2579>. Access on: 4 oct. 2018. p. 236. Our translation. Our italics. Original: "no que pese o art. 68.2 do Pacto de San José da Costa Rica se referir apenas à penalidade de cunbo patrimonial, a parte extrapecuniária das sentenças da Corte Interamericana de Direitos Humanos pode ser executada no âmbito do Poder Judiciário brasileiro [...]". 
from the Inter-American System formalized in the context of the cases we past explored, revoking the Amnesty Law, in a sense that it is necessary for the

[...] Brazilian State to reconsider its position, moving away from the authoritarian paradigm and running towards the effective protection of human rights, confronting its past in order to contribute to the reparation of victims and the non-repetition of violence by the State ${ }^{67}$.

However, as confirmed by Piovesan ${ }^{68}$, the region (Latin America), still lives with the reminiscences of the legacy of dictatorial authoritarian regimes, with a culture of violence and impunity, the low density of States of Law and the precarious tradition of respect for human rights, which makes it difficult to hold accountable those who violate human rights in the country (Brazil). And as marked by Hall and Scherf ${ }^{69}$, there is still a great internal resistance on the part of the Brazilian Government and the competent institutions to accuse, prosecute and condemn these violators, making it hard to bring justice to those who have been subjected to various inhumane practices. Professor Hillebrecht considers as well the participation on the individual level, by legislators and members of the Judicial power, who might fear, retaliation, political persecution and even the loss of their positions in complying with the decisions of the Inter-American System that defy the hegemonic interests of the political elites in the country:

[...] judges and legislators might have a lot to lose if they push for compliance with a human rights tribunal's ruling. Legislators might fear the effects of compliance for their own positions and their preferred policies. Judges might be threatened by the long reach of international law into their jurisprudence. Any of these political actors might

67 BRAGATO, Fernanda Frizzo; COUTINHO, Isabella Maraschin. A efetivação do direito à memória e à verdade no contexto brasileiro: o julgamento do caso Julia Gomes Lund pela corte interamericana de direitos humanos. Revista de Direito Internacional, Brasília, v. 9, n. 1, p. 125-142, 23 jul. 2012. Available at: <http://dx.doi. org/10.5102/rdi.v9i1.1594>. Access on: 4 oct. 2018. p. 132. Our translation. Original: "Destarte, é necessário que o Estado brasileiro reveja o seu posicionamento, afastando-se do paradigma autoritário e voltando-se para a eficaz proteção dos direitos bumanos, confrontando o seu passado de modo a contribuir para a reparação das vítimas e para a não repetição da violência estatal". 68 PIOVESAN, Flávia. Direitos humanos e justiça internacional. 7. ed. São Paulo: Saraiva, 2017. p. 143.

69 HALL, Cristina de Carli; SCHERF, Erick da Luz. The failure of the inter-american system for the protection of human rights: the Case Cosme Rosa Genoveva, Evandro de Oliveira and others versus Brazil. (Re)pensando direito, Santo Ângelo, v. 7, n. 14, p. 55-70, dez. 2017. Available at: <http://local.cnecsan.edu.br/revista/index. php/direito/article/view/530/407>. Access on: 6 mar. 2018. p. 5570. simply have a preference for the status quo and disagree with the Inter-American tribunals' rulings. The legal mandate embodied in the tribunals' rulings and recommendations can sometimes be sufficient to overcome these challenges, but legislative and judicial reluctance to comply or to oversee the executive's handling of compliance can slow or stop the compliance process ${ }^{70}$.

In sum, in the case Gomes Lund versus Brazil, the sentence propelled by the Inter-American Court found certain positive achievements, the country has undertaken concrete actions in favor of civil and administrative accountability of perpetrators of human rights violations during the military regime, however, in the criminal part of the sentence (on penal responsibility), Brazilian institutions have been reluctant to the prosecution of those accountable for the deaths in the Araguaia Guerrilla, mainly due to the Amnesty Law in effect in the country.

It is possible, then, after taking into account the constructivist approach of Hillebrecht, to recognize that there are some measures set by the Inter-American System that are more political costly than others, therefore, are harder to be executed in the national level, because they might face political struggles related to the national institutions and even individuals involved in the implementation of the System's sentences in the national legal order, being these some of the determining factors for non-compliance with the Court.

\subsection{The Brazilian Supreme Court and the impossibility of imprisonment of the unfaithful depositary in Brazil}

Until 2008, the civil arrestment of individuals in Brazil was possible in two distinct occasions according to the country's Constitution of 1988: Article 5, LXVII - "there will be no civil prison for debt, except that of the person responsible for voluntary and inexcusable default of food obligation and that of the unfaithful depositary"

70 HILLEBRECHT, Courtney. The domestic mechanisms of compliance with international human rights law: case studies from the inter-american human rights system. Human Rights Quarterly, [S.L.], v. 34, n. 4, p. 959-985, 2012. Johns Hopkins University Press. http://dx.doi.org/10.1353/hrq.2012.0069. Available at: <https:// muse.jhu.edu/article/489370/pdf>. Access on: 6 mar. 2018. p. 14. 71 BRASIL. Constituição (1988). Constituição da República Federativa do Brasil: promulgada em 05 de outubro de 1988. Available at: $<$ https://legislacao.planalto.gov.br/legisla/legislacao.nsf/viwTodos /509f2321d97cd2d203256b280052245a?OpenDocument\&Highlig 
In Roman law, the nexum arises, which was the solemn act of self-attachment of the debtor himself, executed through the per manus iniectionem, which comprised legis actiones (754 to 149 BC). However, this type of arrest was not seen with good eyes before the Roman plebs when, in $326 \mathrm{BC}$, the civil prison was abolished and replaced with the patrimonial responsability. It was the Lex Poetelia Papiria that abolished personal execution and gave rise to the patrimonial responsibility ${ }^{72}$.

Notwithstanding, the first international to attempt to exclude the civil imprisonment due to debts was the "International Covenant on Civil and Political Rights" - adopted by the General Assembly of the United Nations on 19 December 1966 (and promulgated in Brazil through the Decree No. 592, of July 6, 1992) - in which states in its eleventh article that: "no one shall be imprisoned merely on the ground of inability to fulfil a contractual obligation" ${ }^{73}$.

In the matter of regional protection of human rights and basic liberties, the Inter-American System (which Brazil is part of since 1992), formalized in 1969, the American Convention on Human Rights (or Pact San José, Costa Rica), that stablishes in article 7 that: "no one shall be detained for debt. This principle shall not limit the orders of a competent judicial authority issued for nonfulfillment of duties of support" ${ }^{\prime \prime 4}$.

Nonetheless, in 2008, the Brazilian Supreme Court decided to rule in favor of the American Convention, therefore excluding the possibility of imprisonment of the unfaithful depositary - instituted by Article 5 LXVII, of the Federal Constitution of 1988 - a decision that was headed by the Justice Gilmar Mendes, that stated the following:

Since the accession of Brazil, without reservation, to the International Covenant on Civil and Political

ht=1, constituição\&AutoFramed $>$. Access on: 13 sep. 2018.

72 FILARDI, Luciana. Considerações sobre a natureza jurídica do depositário infiel. 2011. 38 f. Paper (Undergraduation) - Law Department, Universidade Presidente Antônio Carlos, Barbacena, 2011. Available at: <http://www.unipac.br/site/bb/tcc/tcc894f71985609fa136653b25691a2d9cb.pdf>. Access on: 6 mar. 2018. p. 24.

73 UNITED NATIONS. International covenant on civil and political rights. New York. Available at: <https://treaties.un.org/doc/publication/unts/volume\%20999/volume-999-i-14668-english.pdf>. Access on: 13 sep. 2018.

74 ORGANIZATION OF AMERICAN STATES. American convention on buman rights "Pact of San Jose, Costa Rica". San Jose, Available at: <http://www.oas.org/dil/treaties_B-32_American_Convention_on_Human_Rights.pdf>. Access on: 13 sep. 2018.
Rights (Article 11) and the American Convention on Human Rights - Pact of San José, Costa Rica (Article 7, 7), both in 1992, there is no longer any legal basis for the civil imprisonment of the unfaithful depositary, since the special character of these international human rights diplomas reserves for them a specific place [...] in the Brazilian legal $\operatorname{order}^{75}$.

The interpretation changes occurred in the judgment of the Extraordinary Resources (RE 349703) and (RE 466343) and the Habeas Corpus (HC 87585). And with the new understanding, the Brazilian Supreme Court adapted not only to the American Convention on Human Rights (1969), but also to the UN International Covenant on Civil and Political Rights (1966) ${ }^{76}$, on this specific case. The Brazilian Supreme Court has complied then with the juridical hermeneutics coming from international human rights law, changing therefore its understanding over a human rights matter, acknowledging that:

Magistrates and Courts, in the exercise of their
interpretive activity, especially in the context of
international human rights treaties, must observe
a basic hermeneutical principle (such as the
one proclaimed in Article 29 of the American
Convention on Human Rights), to give primacy
to the rule that is more favorable to the human
person, in order to grant him [or her] the widest
legal protection 7 .

In this sense, the highest judicial authorities of the country represented in the Brazilian Supreme Court by the Justices, had together changed the interpretation of a constitutional norm in order to comply with international human rights rules and norms of interpretation, more specifically, with the Inter-American Convention and the Covenant on Civil and Political Rights, through

75 RAMOS, André de Carvalho. Curso de direitos humanos. 4. ed. São Paulo: Saraiva, 2017. p. 478. Our translation.

76 SUPREMO TRIBUNAL FEDERAL. Depositário infiel: jurisprudência do STF muda e se adapta ao Pacto. 2009. Portal de Notícias. Available at: < http://www.stf.jus.br/portal/cms/verNoticiaDetalhe.asp?idConteudo=116379>. Access on: 4 oct. 2018.

77 FELICIANO, Guilherme Guimarães. A prisão civil do depositário judicial infiel economicamente capaz: um outro olhar. Rev. Trib. Reg. Trab. $3^{\text {a }}$ Reg., Belo Horizonte, v. 79, n. 49, p. 55-79, jan./may 2009. Available at: <https://www.trt3.jus.br/escola/download/ revista/rev_79/guilherme_guimaraes_feliciano.pdf $>$. Access on: 4 oct. 2018. p. 60. Our translation. Original: "Os magistrados e Tribunais, no exercício de sua atividade interpretativa, especialmente no âmbito dos tratados internacionais de direitos humanos, devem observar um princípio hermenêutico básico (tal como aquele proclamado no Artigo 29 da Convenção Americana de Direitos Humanos), consistente em atribuir primazia à norma que se revele mais favorável à pessoa bumana, em ordem a dispensar-lhe a mais ampla proteção jurídica". 
which Brazil had taken a commitment to fulfill all the obligations set by these treaties ratified by the country, showing that in this specific case, the Brazilian Supreme Court ruled in favor of the most favorable norm for the experimentation of human dignity.

This is a case for compliance, even though the Brazilian Supreme Court was not following a jurisprudence from the System, but instead a human right normative, it showed the willing of the country and its institutions at that time to comply with human rights norms even before the State could be submitted to a trial due to violations of such norm. This decision propelled by the Supreme Court can be considered less political costly, because it does not attack directly the interests of any important actor in the process of decision taken underneath the Public Power in the country and it does not require profound changes in Brazilian institutions, therefore making it easier for compliance with international human rights rules as the ones stated in the American Convention on Human Rights.

\section{Final Considerations}

The first aim of this article was to analyze the response of the Brazilian Supreme Court to the norms and jurisprudence of the Inter-American System of Human Rights and how they exercise influence or not in the institutional and juridical developments that take place in the Court. In order to do that, we analyzed the cases of: 1) the human rights violations involving Brazil in the case: "Gomes Lund and others versus (v.) Brazil", and also in the recent case "Herzog and others v. Brazil", which have similar backgrounds and demands, in order to analyze whether they had or not influence on the Court's understandings; and 2) the decision of the Brazilian Supreme Court over the impossibility of imprisonment of the unfaithful depositary based on the American Convention of Human Rights. And as a secondary goal, we intended to identify the reasons why the Court has complied or not with the rulings or norms coming from the Inter-American System in the cases we have chosen to analyze.

As it could be seen throughout this research, the Inter-American System has grown over the years along with its jurisdiction, jurisprudence, and its attempts to take actions into the promotion of human rights in the
Americas, however, the System seems to have failed in some aspects, mainly about implementing its sentences and recommendations in the national level of the States-part of the American Convention on Human Rights.

The reasons to that can hardly ever be found if we look to the actions of the Inter-American System through Realist's or Liberalist's lenses, as argued in Section 1. Therefore, taking into account the Constructivist way of seeing the international system (Alexander Wendt) and the relation between Human Rights Tribunals and domestic institutions (Courtney Hillebrecht), a broader perspective could be found, offering more complex tools to analyze the way the States respond to human rights norms coming from the international society.

Notwithstanding, it was possible to recognize that the Brazilian Supreme Court showed no compliance with rulings set by the Inter-American System in the case "Gomes Lund and others v. Brazil" and "Herzog and others v. Brazil", showing resistance in changing the Amnesty Law and proved that the country's domestic institutions are still inclined to the spirit of conservatism and authoritarianism that are reminiscent of the dictatorial legacy result of the rise of reactionary ideals during the Cold War. Having the System, in this specific case, caused little impact in the understandings and institutional developments that take place in Brazil's highest Court.

Differently, in the other situation analyzed, the Brazilian Supreme Court ruled in favor of a norm that comes from the American Convention on Human Rights, installing the impossibility of civil arrestment of the unfaithful depositary that was legal until 2008. We came to realize that the reason for that might be because this move coming from the country's Supreme Court was less political costly than what the Public Power in Brazil would have to do to fulfill all the measures set by the Inter-American System in the case Gomes Lund and Herzog.

What we would like to propose for future researches, is to elaborate alternatives for this gap in the Inter-American System, specially suggestions of new mechanisms of governance that could be built to potentialize the effect of the System's jurisdiction in national levels. Even though authors showed that a possible response is to have domestic actors pressing the Public Power to act towards compliance, we believe that certain mecha- 
nisms could be developed in the international level to push the States into promoting the core of rights they have committed to protect when they became members of Systems for regional protection of human rights such as the Inter-American one.

\section{References}

ABRAMOVICH, Víctor. From massive violations to structural patterns: new approaches and classic tensions in the Inter-American human rights system. Sur, Rev. Int. Direitos Human., São Paulo, v. 6, n. 11, p. 6-39, Dec. 2009. Available at: <http://www. scielo.br/scielo.php?script $=$ sci_arttext\&pid $=$ S1806$64452009000200002 \& \operatorname{lng}=$ en\&nrm $=$ iso $>$. Access on: 15 feb. 2018.

ALVES, Lucélia de Sena; LIMA, Renata Mantovani de. A efetividade do ativismo jurídico transnacional no sistema interamericano de direitos humanos: uma análise a partir de casos contra o Brasil. Revista de Direito Internacional. Brasília, v. 10, n. 2, p. 238-249, 4 jan. 2014. Available at: <http://dx.doi.org/10.5102/rdi.v10i2.2558>. Access on: 4 oct. 2018.

BATES, E. S. Sophisticated constructivism in human rights compliance theory. European Journal of International Law, [S.1.], v. 25, n. 4, p. 1-20, 1 nov. 2014. Available at: < https://doi.org/10.1093/ejil/chu084>. Access on: 19 feb. 2018.

BETHELL, Leslie; ROXBOROUGH, Ian. The impact of the cold war on Latin America. In: LEFFLER, Melvyn P.; PAINTER, David S. (Ed.). Origins of the cold war: an international history. 2. ed. New York; Abingdon: Routledge, 1994. p. 299-316.

BOBBIO, Norberto. Teoria geral da política: a filosofia política e as lições dos clássicos. Rio de Janeiro: Elsevier, 2000.

BRAGATO, Fernanda Frizzo; COUTINHO, Isabella Maraschin. A efetivação do direito à memória e à verdade no contexto brasileiro: o julgamento do caso Julia Gomes Lund pela corte interamericana de direitos humanos. Revista de Direito Internacional, Brasília, v. 9, n. 1, p. 125-142, 23 jul. 2012. Available at: < http://dx.doi. org/10.5102/rdi.v9i1.1594>. Access on: 4 oct. 2018.

BRASIL. Constituição (1988). Constituição da República Federativa do Brasil: promulgada em 05 de outubro de
1988. Available at: <https://legislacao.planalto.gov.br/ legisla/legislacao.nsf/viwTodos/509f2321d97cd2d203 256b280052245a? OpenDocument\&Highlight=1, const ituição\&AutoFramed>. Access on: 13 sep. 2018.

CEIA, Eleonora Mesquita. A jurisprudência da Corte Interamericana de Direitos Humanos e o desenvolvimento da proteção dos direitos humanos no Brasil. $R$. EMERJ, Rio de Janeiro, v. 16, n. 61, p. 113-152, jan. 2013. Available at: <http://www.emerj.tjrj.jus.br/revistaemerj_online/edicoes/revista61/revista61_113. pdf $>$. Access on: 6 mar. 2018.

CHARVET, John; NAY, Elisa Kaczynska. The liberal project and buman rights: the theory and practice of a new world order. Cambridge: Cambridge University Press, 2008.

CIDH. AMERICAN CONVENTION ON HUMAN RIGHTS. 1969. Available at: <https://www.cidh.oas. org/basicos/english/basic3.american\%20convention. htm> Access on: 4 oct. 2018.

CIDH. RELATÓRIO n 71/15, Caso 12.879: relatório de mérito: Vladimir Herzog e outros Brasil. 2015. Available at: <http://www.oas.org/es/cidh/decisiones/ corte/2016/12879FondoPt.pdf $>$. Access on: 4 oct. 2018.

CORTE INTERAMERICANA DE DERECHOS HUMANOS. Brasil es responsable por no investigar crimen de lesa humanidad cometido contra el periodista Vladimir Herzog. 2018. Press Release. Available at: <http://www.corteidh.or.cr/docs/comunicados/cp_25_18.pdf>. Access on: 4 oct. 2018.

CORTE INTERAMERICANA DE DERECHOS HUMANOS. Caso Herzog y otros vs. Brasil: sentencia de 15 de marzo de 2018. 2018. Available at: < http:/ /www. corteidh.or.cr/docs/casos/articulos/seriec_353_esp. pdf $>$. Access on: 4 oct. 2018.

DEUDNEY, Daniel. Anarchy and violence interdependence. In: BOOTH, Ken (Ed.). Realism and world politics. New York: Routledge, 2011. p. 17-34.

DUNNE, Tim; HANSON, Marianne. Human rights in international relations. In: GOODHART, Michael (Ed.). Human rights: politics and practice. Oxford: Oxford University Press, 2009. p. 61-76.

FELICIANO, Guilherme Guimarães. A prisão civil do depositário judicial infiel economicamente capaz: um outro olhar. Rev. Trib. Reg. Trab. $3^{a}$ Reg., Belo Horizon- 
te, v. 79 , n. 49, p. 55-79, jan./may 2009. Available at: <https://www.trt3.jus.br/escola/download/revista/ rev_79/guilherme_guimaraes_feliciano.pdf $>$. Access on: 4 oct. 2018.

FILARDI, Luciana. Consideracõos sobre a natureza jurídica do depositário infiel. 2011. 38 f. Paper (Undergraduation) - Law Department, Universidade Presidente Antônio Carlos, Barbacena, 2011. Available at: <http:// www.unipac.br/site/bb/tcc/tcc-894f71985609fa136653b25691a2d9cb.pdf>. Access on: 6 mar. 2018.

FLORES, Joaquín Herrera. La reinvención de los derechos bumanos. Andalucía: Atrapasueños, 2008.

GEUSS, Raymond. The idea of a critical theory: Habermas and the Frankfurt School. Cambridge: Cambridge University Press, 1981.

GREGG, Benjamin. Human rights as social construction. Cambridge: Cambridge University Press, 2011.

GROVOGUI, Siba N. Mind, body, and gut!:elements of a postcolonial human rights discourse. 2006. Available at: <http:/ / digitalcommons.law.umaryland.edu/cgi/ viewcontent.cgi?article $=1002 \&$ context $=$ iclc_papers $>$. Access on: 15 feb. 2018.

HALL, Cristina de Carli; SCHERF, Erick da Luz. The failure of the inter-american system for the protection of human rights: the Case Cosme Rosa Genoveva, Evandro de Oliveira and others versus Brazil. (Re) pensando direito, Santo Ângelo, v. 7, n. 14, p. 55-70, dez. 2017. Available at: <http://local.cnecsan.edu.br/revista/index.php/direito/article/view/530/407>. Access on: 6 mar. 2018.

HILLEBRECHT, C. Rethinking compliance: the challenges and prospects of measuring compliance with international human rights tribunals. Journal of Human Rights Practice, [S.L.], v. 1, n. 3, p. 362-379, 16 set. 2009. Available at: <https://academic.oup.com/jhrp/articleabstract/1/3/362/2188667>. Access on: 19 feb. 2018.

HILLEBRECHT, Courtney. The domestic mechanisms of compliance with international human rights law: case studies from the inter-american human rights system. Human Rights Quarterly, [S.L.], v. 34, n. 4, p. 959-985, 2012. Johns Hopkins University Press. http://dx.doi. org/10.1353/hrq.2012.0069. Available at: <https:// muse.jhu.edu/article/489370/pdf>. Access on: 6 mar. 2018.

KEOHANE, Robert O. International institutions: two approaches. International Studies Quarterly, [S.L], v. 4, n. 32, p. 379-396, dec. 1988. Available at: < https://edisciplinas.usp.br/pluginfile.php/161137/mod_resource/ content/1/Keohane 1988-International Institutionstwo approaches.pdf>. Access on: 19 feb. 2018.

LARA, Ricardo; SILVA, Mauri Antônio da. A ditadura civil-militar de 1964: os impactos de longa duração nos direitos trabalhistas e sociais no Brasil. Serviço Social \& Sociedade, [S.L.], n. 122, p. 275-293, jun. 2015. Available at: <http://www.scielo.br/pdf/sssoc/n122/01016628-sssoc-122-0275.pdf>. Access on: 6 mar. 2018.

LEFFLER, Melvyn P.; PAINTER, David S. Introduction. In: _ (Ed.). Origins of the cold war an international history. 2. ed. New York; Abingdon: Routledge, 1994. p. 1-12.

MAZOWER, Mark. The strange triumph of human rights. The Historical Journal, [s.l.], v. 47, n. 2, p. 379-398, jun. 2004. Cambridge University Press (CUP). http:// dx.doi.org/10.1017/s0018246x04003723. Available at: $<$ https://www.mazower.com/articles/HJ.pdf $>$. Access on: 15 feb. 2018.

MAZZUOLI, Valério de Oliveira. Curso de direito internacional público. 10. ed. São Paulo: Revista dos Tribunais, 2016.

MAZZUOLI, Valerio de Oliveira. O controle jurisdicional da convencionalidade das leis. 2. ed. São Paulo: Revista dos Tribunais, 2011.

MORAVCSIK, Andrew. Explaining international human rights regimes: liberal theory and western Europe. European Journal of International Relations, London, Thousand Oaks, CA and New Dheli, v. 1, n. 2, p. $157-$ 189, jan. 1995. Available at: <https://www.princeton. edu/ amoravcs/library/explain.pdf $>$. Access on: 19 feb. 2018.

NASCIMENTO, Durbens Martins. A Guerrilha do Araguaia: paulistas e militares na Amazônia. 2000. 199 f. Dissertation (Masters) - Planning of Development Course, Universidade Federal do Pará, Belém, 2000. Available at: <http://www.repositorio.ufpa.br/jspui/ bitstream/2011/2458/1/Dissertacao_GuerrilhaAraguaiaPaulistas.pdf >. Access on: 6 mar. 2018.

ORGANIZATION OF AMERICAN STATES. American Convention On Human Rights "Pact Of San Jose, Costa Rica". San Jose, Available at: <http://www.oas.org/dil/ treaties_B-32_American_Convention_on_Human_ 
Rights.pdf>. Access on: 13 sep. 2018.

PEIXOTO, Rodrigo Corrêa Diniz. Memória social da Guerrilha do Araguaia e da guerra que veio depois. Bol. Mus. Para. Emílio Goeldi. Cienc. Hum., Belém, v. 6, n. 3, p. 479-499, dez. 2011. Available at: <https:// www.google.com.br/url? sa $=\mathrm{t} \& \mathrm{rct}=\mathrm{j} \& \mathrm{q}=\&$ esrc $=\mathrm{s} \& \mathrm{~s}$ ource $=$ web\&cd $=1 \& \mathrm{cad}=$ rja\&uact $=8 \&$ ved $=0$ ahUK Ewib2-vm5trZAhWHUJAKHXgcCOcQFggoMAA \&url=http://www.scielo.br/pdf/bgoeldi/v6n3/02. pdf\&usg=AOvVaw3ljnLiHqli6_bordaLC09q > . Access on: 6 mar. 2018.

PINHEIRO, Paulo Sergio. Democratic consolidation and buman rights in Brazil. 1998. The Helen Kellogg Institute for International Studies. Available at: <https:// kellogg.nd.edu/sites/default/files/old_files/documents/256_0.pdf>. Access on: 15 feb. 2018.

PIOVESAN, Flávia. Direitos humanos e justiça internacional. 7. ed. São Paulo: Saraiva, 2017.

PIOVESAN, Flávia. Direitos humanos e o direito constitucional internacional. 15. ed. São Paulo: Saraiva, 2015.

RAMOS, André de Carvalho. Curso de direitos humanos. 4. ed. São Paulo: Saraiva, 2017.

RAWLS, John. The law of peoples: with "The Idea of Public Reason Revisited". Cambridge: Harvard University Press, 1999.

RESENDE, Augusto. A executividade das sentenças da Corte Interamericana de Direitos Humanos no Brasil. Revista de Direito Internacional, Brasília, v. 10, n. 2, p. 227-236, 4 jan. 2014. Available at: <http://dx.doi. org/10.5102/rdi.v10i2.2579>. Access on: 4 oct. 2018.

SCHÄFER, Gilberto et al. Os controles de convencionalidade tradicional e interamericano: institutos distintos ou duas faces da mesma moeda?. Revista de Direito Internacional, Brasília, v. 14, n. 3, p. 216-242, dec. 2017. Available at: <https://www.publicacoes.uniceub.br/ rdi/article/view/4811>. Access on: 4 oct. 2018.

SILVA, Carla Ribeiro Volpini; WANDERLEY JU-
NIOR, Bruno. A responsabilidade internacional do Brasil em face do controle de convencionalidade em sede de direitos humanos: conflito de interpretação entre a jurisdição da Corte Interamericana de Direitos Humanos e o Supremo Tribunal Federal quanto a Lei de anistia. Revista de Direito Internacional, Brasília, v. 12, n. 2, p. 611-629, 31 dec. 2015. Available: <http://dx.doi. org/10.5102/rdi.v12i2.3699>. Access on: 4 oct. 2018.

SUPREMO TRIBUNAL FEDERAL. Depositário infiel: jurisprudência do STF muda e se adapta ao Pacto. 2009. Portal de Noticias. Available at: <http:// www.stf.jus.br/portal/cms/verNoticiaDetalhe. asp?idConteudo=116379> . Access on: 4 oct. 2018.

UNITED NATIONS. International covenant on civil and political rights. New York. Available at: <https://treaties. un.org/doc/publication/unts/volume\%20999/volume-999-i-14668-english.pdf>. Access on: 13 sep. 2018.

WALT, Stephen M. International relations: one world, many theories. Foreign Policy, [S.L.], n. 110, p. 29-46, Spring 1998. JSTOR. http://dx.doi. org/10.2307/1149275. Available at: <https://www. jstor.org/stable/1149275?seq=1\#page_scan_tab_contents>. Access on: 13 sep. 2018.

WENDT, Alexander. Anarchy is what states make of it: the social construction of power politics. International Organization, [S.L], v. 46, n. 2, p. 391-425, jan. 1992. Available at: <http://www.jstor.org/stable/2706858>. Access on: 19 feb. 2018.

WENDT, Alexander. Social theory of international politics. New York: Cambridge University Press, 1999. 
Para publicar na Revista de Direito Internacional, acesse o endereço eletrônico www.rdi.uniceub.br ou www.brazilianjournal.org.

Observe as normas de publicação, para facilitar e agilizar o trabalho de edição. 